\title{
A petrochemical study of calcic amphiboles from the East Bull Lake anorthosite-gabbro layered complex, District of Algoma, Ontario
}

\section{Choudari Kamineni}

D. Choudari Kamineni, Contrib Mineral Petrol (1986) 93:471-481 request that the following amendments be noted: on page 476 , enclenitic should read edenitic; on page $478, E_{\max }$ should have been omitted in equitation (3) and (4) right hand column. 